\title{
Czy zaangażowanie w grę jest racjonalne? Imersja emocjonalna w zabawie, zarządzaniu i sporcie
}

Is engaging in games rational? Emotional immersion in fun, management and sport

\author{
Jan F. Jacko, Matgorzata Jacko \\ Uniwersytet Jagielloński, Akademia Wychowania Fizycznego w Krakowie \\ 379@wp.eu | ORCID: 0000-0002-5654-1039 \\ natanek7@hotmail.com | ORCID: 0000-0002-7376-8681
}

\begin{abstract}
The study presents a phenomenological analysis of emotional immersion in fun, sport and management games. The analysis leads to some explanatory hypotheses, which answer the title question of the text. They come from some theories of rational action. According to them, two types of emotional immersion can take place: the one that meets the requirements of rationality and the one that does not meet them.
\end{abstract}

Keywords: impression management, quality management, fun, sport, physical culture, rational action, immersion 



\section{Wprowadzenie}

W niniejszym teście termin „gra” oznacza sytuacje, w których obowiązują reguły określające cel i sposób działania'. Studium dotyczy zjawiska imersji emocjonalnej, polegającej na psychicznym „zanurzeniu się” w rzeczywistość gry. Odróżnia się imersję zmysłową od emocjonalnej. Imersja zmysłowa to wrażenie realności świata przedstawionego w grze, np. doświadczenie głębi przestrzeni w grze wirtualnej (Baños i in., 2004; Jennett $\mathrm{i}$ in., 2008). Imersja emocjonalna to pobudzenie i zaabsorbowanie grą (Baños i in., 2004; Jennett $\mathrm{i}$ in., 2008) ${ }^{2}$. W tekście imersję emocjonalną nazywa się po prostu „imersją".

W przeżyciu imersji emocje ${ }^{3}$ gracza prezentują wartość ${ }^{4}$ gry lub wartości do niej należące tak, jakby były ważniejsze dla niego, niż faktycznie

1 Gra w sensie systemowym to uporządkowany zbiór (system) reguł działania określających cel i sposoby jego osiągania. Grą w znaczeniu funkcjonalnym są akty człowieka spełniane według owych reguł. W tym sensie „gra” oznacza granie - udział w grze przez gracza. Gra w sensie sytuacyjnym to wydarzenia dokonujące się zgodnie z owymi regułami - np. partia szachów, mecz sportowy, spotkanie negocjacyjne. Przykładowo, reguły gry w piłkę nożną to gra w sensie systemowym, zachowanie piłkarzy w trakcie meczu to gra w znaczeniu funkcjonalnym, a mecz piłkarski to gra w sensie sytuacyjnym. Graczem nazywa się osobę spełniającą akty (np. podejmującą decyzje, przeżywającą emocje) zgodnie z regułami gry w sensie systemowym. Takie rozumienie terminu "gra” jest szerokie - obejmuje nie tylko gry towarzyskie (służące zabawie i rozrywce), ale też niektóre sytuacje życiowe i zawodowe. Przykładowo reguły określające cele i sposób prowadzenia negocjacji to gra w sensie systemowym. Interakcje negocjatorów są grami (negocjacjami) w znaczeniu funkcjonalnym. A w sytuacyjnym - negocjacje to wydarzenia, w których trakcie dochodzi do owych zachowań (Jacko, 2013, 2016).

2 Zob. Zhang, Perkis, Arndt, 2017: ,[In the emotional immersion] the user feels emotionally aroused and absorbed by the narrative content of the story. Different from spatial immersion, emotional immersion does not necessarily allow users to feel the »bodily presence « into the scene, but allows them to be cognitively identified and emotionally empathised with one of the characters of the story or avatars in the game world".

3 W tekście termin „emocje” ma znaczenie takie, jakie przypisał mu M. Scheler. W jego ujęciu emocje to pierwotny (nieredukowalny do innych zjawisk i niedefiniowalny) fenomen odzwierciedlania się wartości we wrażliwości człowieka (Davis, Steinbock, 2016). Do realizacji celu pracy nie jest potrzebne roztrząsanie różnicy między emocjami a uczuciami, nastrojami, afektami, sentymentami, choć to odróżnienie może być przydatne dla innych badań (Mandryk, Inkpen, 2004; Ravaja i in., 2005, 2008, 2009).

4 Termin „hierarchia wartości” lub „system wartości” oznacza w tekście system preferencji, którym kieruje się podmiot przy podejmowaniu decyzji (Hansson, Grüne-Yanoff, 2018). Termin „wartość” niesie w tym kontekście sens subiektywny - oznacza to, co jest cenione przez podmiot. Takie określenie wartości ma charakter regulujący i nie przesądza 
są - przykładowo, gdy ktoś, kibicując swojej drużynie, przeżywa jej sukces lub fiasko tak, jakby były one czymś dla niego najważniejszym w danej chwili, choć w rzeczywistości nie stanowią dla niego aż tak istotnej wartości. Skoro imersja we wskazany tu sposób zmienia percepcję emocjonalną, to może skłaniać gracza do tego, by dla udziału lub wygranej w grze poświęcił wyżej od nich cenione przez siebie wartości. Ta możliwość stanowi problem, który można wyrazić tytułowym pytaniem pracy. Celem tekstu jest sformułowanie hipotez będących odpowiedzią na to pytanie.

Jeśli gracz wybiera środki działania, o których wie, że nie prowadzą go do obranego celu - podejmuje decyzję nieracjonalną instrumentalnie. Decyzjami nieracjonalnymi aksjologicznie gracz zaprzecza przyjętemu przez siebie systemowi wartości. Imersja jest nieracjonalna, gdy stanowiące ją emocje skłaniają ich podmiot do podejmowania instrumentalnie lub aksjologicznie nieracjonalnych decyzji ${ }^{5}$.

W drodze do odpowiedzi na tytułowe pytanie przeprowadzona zostanie fenomenologiczna analiza przeżycia imersji, określająca intencjonalną strukturę zaangażowania w gry należące do trzech dziedzin - do zabawy, sportu i zarządzania. W kontekście tych analiz sformułowane zostaną hipotezy wyjaśniające fenomen imersji, które zaczerpnięto z teorii racjonalnego działania.

Wybór wspomnianych trzech obszarów nie jest przypadkowy. Zabawa stanowi przykład zaangażowania w postawie estetycznej, którą kontrastuje się z postawą praktyczną, typową dla zarządzania ${ }^{6}$. Różnice i związki

trwającego od tysiącleci sporu o to, czy istnieją jakieś dobra cenne niezależnie od preferencji podmiotu.

5 Termin „racjonalność decyzji” oznacza w pracy dwa sposoby i dwie cechy podejmowania decyzji. Racjonalność instrumentalna polega na wybieraniu - przez gracza - takich środków działania, które w świetle jego wiedzy są skutecznym sposobem osiągnięcia założonego celu. Racjonalność aksjologiczna decyzji polega na tym, że jest ona zgodna z hierarchią wartości założoną przez jej podmiot (Weber, 1985, s. 565). Racjonalnym podmiotem nazywa się osobę podejmującą decyzje racjonalne instrumentalnie i aksjologicznie. Racjonalną postawą określać się będzie skłonność jednostki do podejmowania takich decyzji.

6 Zabawa i zarządzanie nie są zjawiskami rozłącznymi: można zarządzać zabawą („przemysłem rozrywki”) lub bawić się, zarządzając. Poza tym zachodzi analogia między grami należącymi do zabaw a tymi zaliczanymi do zarządzania. Jednak jest między nimi zasadnicza różnica: zabawa wymaga przyjęcia postawy estetycznej, a zarządzanie - praktycznej (Jacko, 2013; 2016). 
między tymi postawami będą objaśniane w pracy. Przykłady zaangażowania w gry sportowe ${ }^{7}$ zilustrują zjawiska pośrednie między zabawą a zarządzaniem, gdyż w grach należących do sportu ich podmiot może przyjmować postawę estetyczną lub praktyczną.

\section{Stan badań}

Początkowe badania imersji dotyczyły głównie gier komputerowych i narracyjnych oraz następstw tego przeżycia (Anderson, Dill, 2000; Bushman, Anderson, 2002; Grüsser, Thalemann, Griffiths, 2007). Potem zaczęto badać jego subiektywne aspekty w tych grach (Komulainen, Takatalo, Lehtonen, Nyman, 2008; Nacke i in., 2009), np. przeżycie flow (Csíkszentmihályi, 1975, 1990), stopni imersji (Dansky, 2006), zaangażowania (engagement) w grę i zaaabsorbowania (engrossment) grą (Brown, Cairns, 2004; Nacke, Lindley, 2008; Jennett i in., 2008), organicznych (organic) i międzyosobowych (interactive) emocji w grze (Hochschild, 1979) oraz kognitywnych aspektów udziału w niej (Ortony i in., 1990). Uczeni dostrzegają deficyt analiz fenomenologicznych, które mogłyby dać ogólną definicję tego zjawiska, a jest ona potrzebna m.in. po to, by precyzyjnie określić zmienne badań dotyczących imersji emocjonalnej i trafnie interepretować ich wyniki (Brown, Cairns, 2004, s. 1297; Lindley, Nacke, Sennersten, 2008; Ravaja i in., 2009).

W pracy przedstawione są argumenty za tym, że imersja może wystąpić w obszarach praktycznego zaangażowania człowieka. Takie ujęcie wolno uznać za nietypowe, bo termin „imersja” jak dotąd rezerwowano dla opisu przeżycia udziału w grach towarzyskich służących zabawie oraz w percepcji estetycznej (IGI Global, b.d.). Dlatego koncepcje określające to zjawisko należą głównie do ludologii i estetyki. Artykuł stanowi

7 W tekście przyjmuje się ustawowe pojęcie sportu (Ustawa z dnia 25 czerwca $2010 \mathrm{r}$. o sporcie [Dz.U. $2010 \mathrm{nr} 127$ poz. 857], art. 2): „1. Sportem są wszelkie formy aktywności fizycznej, które przez uczestnictwo doraźne lub zorganizowane wpływają na wypracowanie lub poprawienie kondycji fizycznej i psychicznej, rozwój stosunków społecznych lub osiągnięcie wyników sportowych na wszelkich poziomach. 1a. Za sport uważa się również współzawodnictwo oparte na aktywności intelektualnej, którego celem jest osiągnięcie wyniku sportowego. 2. Sport wraz z wychowaniem fizycznym i rehabilitacją ruchową składają się na kulturę fizyczną". 
propozycję ulokowania badań nad imersją w teorii ludzkiego działania, obejmującej te dziedziny, ale też wykraczającej poza nie.

Odróżnienie imersji racjonalnej od nieracjonalnej nie zostało dotąd sformułowane explicite, choć sygnalizuje się je na marginesie publikacji dotyczących uzależnień, gier hazardowych i psychologii gier (Ballabio i in., 2017; Detez i in., 2019; Jacko, 2018b; Seah, Cairns, 2008; Van Gordon i in., 2018). Niniejsze studium jest propozycją doprecyzowania tego odróżnienia.

Termin „imersja” nie należy do kanonicznej terminologii nauk o zarządzaniu i o sporcie. Są jednak w nich opracowania zjawiska imersji. Dotyczą go m.in. koncepcje i badania na temat motywacji oraz motywowania pracowników (Frey, Osterloh, 2001; Latham, 2012, s. 61-120) czy sportowców (Roberts, Treasure, 2018), wypalenia zawodowego (Schaufeli, Maslach, Marek, 1996) i taktyk rozwoju zawodowego, przykładowo w koncepcji embodied career (Coupland, 2015). Dlatego fenomen nas interesujący nie jest całkiem nowym obszarem studiów dotyczących zarządzania i sportu. Nazwanie tego fenomenu zaczerpniętym z ludologii i estetyki terminem ,imersja” sygnalizuje możliwości wykorzystania wiedzy tych nauk do wyjaśniania tego zjawiska.

\section{Gdy gra zaczyna bawić. Wrażenie immanencji gier}

Imersja jest możliwa dzięki postawie estetycznej. Można wyróżnić dwa jej aspekty: bezinteresowność i dystans. Zostały określone w teoriach percepcji estetycznej (Bullough, 1912/1989; Hilgers, 2016; Kant, 2007; King, b.d.; Kreitman, 2006; Shelley, 2013; Stolnitz, 1961).

Postawa bezinteresowna estetycznie to skupienie uwagi i skoncentrowanie emocji na grze, w których to stanach horyzont zaangażowań obejmuje tylko cele i przewidywania należące do niej (tamże). W tej postawie możliwa jest zabawa, jak pokazuje Johan Huizinga w kultowej już książce Homo ludens z 1938 roku.

Swoisty dla postawy estetycznej dystans do rzeczywistości polega na tym, że podmiot jest jakby niezainteresowany jej istnieniem, bo jego uwaga skupia się na przeżyciach. Dystans ten pozwala na doświadczenie 
estetycznych i autotelicznych ${ }^{8}$ wartości, które są jakościami przeżyć (tamże), oraz ich czysto intencjonalnego korelatu, np. rzeczywistości przedstawionej w dziele literackim - na co zwraca uwagę Roman Ingarden (1998). W tym dystansie emocje mogą dotyczyć przeżyć (gdy ktoś delektuje się nimi) i fikcji (gdy gracz jest zaabsorbowany swoimi wyobrażeniami).

Dystans estetyczny pojawia się w zabawie i jest dla niej swoisty. Dlatego nie polega ona na przeżywaniu jakiegoś rodzaju emocji - przyjemnych lub nieprzyjemnych, pozytywnych lub negatywnych. Dzięki owemu dystansowi gracz delektuje się własnymi przeżyciami, także tymi nieprzyjemnymi i negatywnymi, np. strachem lub gniewem. To samo okazuje się zaś trudne w postawie praktycznej, w niej bowiem wymienione emocje stanowią bodziec do działania i nie są przedmiotem kontemplacji.

Dzięki postawie estetycznej emocje mogą odzwierciedlać autoteliczną wartość udziału w grze, jej celów i przebiegu. Przykładowo, można odczuwać zaciekawienie jakimś problemem naukowym lub satysfakcję z dobrze wykonanej pracy także wtedy, gdy nie uważa się jego rozwiązania lub jej wykonania za przydatne do osiągnięcia innych celów. Natomiast w postawie praktycznej podmiot traktuje swoje działania narzędziowo i jego emocje odzwierciedlają instrumentalną wartość zjawisk oraz wykonywanej czynności.

Ktoś, kto przyjmuje postawę estetyczną, może brać pod uwagę otoczenie i konsekwencje gry, w której uczestniczy, ale jeśli wywołuje to emocje, to są one przeżywane jako nienależące do zabawy jej zakłócenie. Przykładowo, jeśli ktoś w trakcie tańca zaczyna się martwić o to, czy wyłączył w domu żelazko, to emocje troski „psują” zabawę tańcem, bo skłaniają do przyjęcia postawy praktycznej. W tej postawie zaczyna się traktować taniec instrumentalnie, tak jakby był jedynie środkiem lub przeszkodą na drodze do osiągnięciu jakiegoś celu. Podobnie choćby wypalenie zawodowe pracownika polega niekiedy na tym, że nie przeżywa on ciekawości lub satysfakcji związanej z wyzwaniami zawodowymi, bo przyjmując postawę czysto praktyczną, traci wrażliwość na autoteliczną wartość swojej pracy.

8 Wartości instrumentalne są cenne lub cenione tylko dlatego, że stanowią narzędzie do osiągnięcia innych wartości. Wartości autoteliczne są cenne lub cenione dla nich samych (bez względu na ich użyteczność). 
Postawa bezinteresowna estetycznie może wypływać z postawy praktycznej - np. gdy ktoś skupia się na realizacji jakiegoś zadania i jakby zapomina (emocjonalnie) o innych sprawach, przestaje się o nie troszczyć. Te postawy czasem też sobie towarzyszą: psychologia zarządzania ukazuje zalety dystansu estetycznego w stresujących sytuacjach, dzięki niemu bowiem podmiot jest bardziej świadom swoich emocji, przez co potrafi nad nimi panować lepiej niż w postawie praktycznej, kiedy jego uwaga jest skoncentrowana na działaniu. Można choćby przyjąć postawę dystansu estetycznego wobec realnego zagrożenia po to, by pohamować strach lub agresję (Blix, 2015). Lęk przed przegraną, przed „straceniem twarzy" lub pragnienie sukcesu nierzadko paraliżują. Dlatego w praktyce trenerskiej dąży się niekiedy do wywołania postawy estetycznej w sportowcach, zachęcając ich do tego, by przestali myśleć o stawce, o którą grają, i potraktowali rozgrywki jako zabawę (Garn, Cothran, 2006). Swoista dla postawy estetycznej przyjemność płynąca z delektowania się przeżyciami może stanowić motywator treningu sportowego (tamże) lub chronić przed wypaleniem zawodowym (Schaufeli, Maslach, Marek, 1996).

Emocje imersji skłaniają do przyjęcia postawy estetycznej i są jej przejawem. Ich bezinteresowność estetyczna polega na tym, że ogniskują się na grze, a nie na jej otoczeniu i następstwach. Dystans estetyczny tego przeżycia pozwala graczowi delektować się autotelicznymi i estetycznymi wartościami gry.

Wrażeniem immanencji gier nazywa się imersję nieprowadzącą do niewiedzy lub „wyparcia” (ze świadomości podmiotu) informacji na temat rzeczywistości i wartości wykraczających poza horyzont gry, w której się uczestniczy. Ulegający temu wrażeniu podmiot jest na niej skupiony i nią pobudzony, ale pozostaje wrażliwy na to, co do niej nie należy. Uwzględnia skutki gry oraz jej kontekst i będzie skłonny ją przerwać lub zmienić jej przebieg, gdy zacznie ona zagrażać wartościom uważanym przez niego za ważniejsze niż udział i sukces w grze. Przykładowo, menadżer może ulegać temu wrażeniu, ogniskując swoją uwagę i emocje na procesie negocjacji, ale będzie korzystał z wiedzy o otoczeniu i przerwie rozmowę, jeśli zajdą jakieś wymagające tego okoliczności, np. ogłoszony zostanie alarm pożarowy. Podobnie uczestnik gry online będzie rozkoszować się swoim w niej udziałem, lecz zakończy ją w zaplanowanym czasie. Wrażenie immanencji gier jest jednak możliwe tylko wtedy, gdy towarzyszy 
mu dystans etyczny do gry - postawa polegająca na tym, że gracz nie jest skłonny poświęcić dla niej realizacji tych celów, które są dla niego od niej ważniejsze (Feezell, 2004; Huhtamo, 2005; King, b.d.)

\section{Gdy gra przestaje być zabawą. Złudzenie immanencji gier}

Wrażenie immanencji gier może się przerodzić w złudzenie immanencji gier, które ma miejsce wtedy, gdy gracz traci dystans etyczny do gry. Wtedy emocje imersji skłaniają gracza, by dla gry poświęcił to, co uważa za cenniejsze od niej. Emocje owe kształtują nieracjonalną aksjologicznie postawę, w której gracz jest gotów działać wbrew przyjętej hierarchii wartości. W takiej postawie postrzega i przeżywa siebie i swoje działanie zgodnie z mechaniką i logiką gry - traci poczucie własnej tożsamości, jak np. szalony aktor, który tak bardzo identyfikuje się ze swoją rolą Napoleona w sztuce teatralnej, że zaczyna się uważać za tę postać historyczną.

W ramach ludologii opisywane są przypadki tego złudzenia. Należy do nich powergaming - zjawisko polegające na tym, że gracz dąży do sukcesu w grze w taki sposób, że podporządkowuje jej swoje życie. Blogi internetowe obfitują w spektakularne opisy tej przemiany, np.: „Po czym poznać Power Gamera? Przekrwione, podkrążone oczy oraz tiki nerwowe i monotonne gadanie o jednej i tej samej grze" (Co-to-znaczy.pl, 2015).

Postawa powergamingu nie jest aksjologicznie racjonalna, bo jest skłonnością do tego, by dla wygranej poświęcić wartości wyżej od niej cenione. Jak zauważa T. L. Taylor (2003, s.302-303), powergaming prowadzi do decyzji, które są instrumentalnie racjonalne jedynie ze względu na cel wyznaczony regułami danej gry. Nie są instrumentalnie racjonalne w odniesieniu do innych celów gracza. Te decyzje mogą być kontrproduktywne, gdy negują powód, dla którego ceni on grę. Przykładowo, może brać w niej udział ze względu na jej klimat i jakość interakcji z innymi jej uczestnikami, ale unicestwiać te wartości dla wygranej (tamże).

Podobne do powergamingu zjawisko występuje w dziedzinie zarządzania i jest określane mianem postawy „praktycznego ekonomizmu”. Polega na tym, że ktoś dla jakiegoś zysku (np. finansowego) poświęca ważniejsze wartości. Praktyczny ekonomizm opiera się na teoretycznym, bazującym na 
założeniu, że „człowiek ma tylko tzw. potrzeby materialne (jadło, mieszkanie itp.) - względnie, że zaspokojenie potrzeb materialnych pociąga za sobą automatycznie zaspokojenie wszystkich innych i szczęście ludzi" (Bocheński, 1987, s. 35). Jak zauważa Józef Maria Bocheński, to stanowisko jest zabobonem, bo nie zgadza się z doświadczeniem, co „widać choćby w krajach bogatych, gdzie potrzeby materialne są zaspokojone z nadmiarem, ale gdzie wielu ludzi, zwłaszcza młodych, czuje się nieszczęśliwymi i cierpi" (tamże).

Można ulegać złudzeniu immanencji gier na wiele sposobów. Bywa, że polega ono na „zaślepieniu sukcesem”, gdy dla jego osiągnięcia ludzie poświęcają to, co bardziej od niego cenią. Niekiedy złudzenie to przyjmuje postać nałogu. Przykładowo, nie sposób wykluczyć, że pracoholik nie uważa swej pracy za coś najistotniejszego w życiu, ale gdy się jej oddaje, traci kontakt emocjonalny z własną hierarchią wartości. Złudzenie czasem opiera się też na myśleniu życzeniowym - gdy pod wpływem imersji gracz nie przyjmuje do wiadomości informacji, jakie uzyskał. Przykładowo, ulegający temu złudzeniu hazardzista może być pewny wygranej, sportowiec zaś tego, że środki dopingujące nie będą szkodliwe, wykryte, ich zażycie nie doprowadzi do dyskwalifikacji - choć obaj dobrze wiedzą o tym, że to jest mało prawdopodobne 9 . Utrata dystansu etycznego do gry przyjmuje niekiedy postać estetyzacji życia, opisanej przez Sørena Kierkegaarda (1814), a opartej na tym, że ktoś przyjmuje postawę estetyczną w sytuacjach wymagających odpowiedzialności. Przykładowo, człowiek może tak dobrze się bawić, sterując dronami bojowymi, że nie przeżywa dylematu moralnego związanego z tym, że zabija ludzi. Podobnie, może dla zabawy dopuszczać się mobbingu lub przestępstw, bo pod wpływem estetyzacji życia jego emocje są niewrażliwe na świat wartości pozaestetycznych.

\section{Zasada otwartości gier a racjonalność gracza}

Jak zauważa m.in. Taylor (2003, s. 306), mylne jest przekonanie, że zaangażowanie gracza ogranicza się tylko do celów wyznaczonych regułami

9 Można się domyślać tego rodzaju motywów stosowania dopingu - np. u Lance’a Armstronga (kolarstwo), Bena Johnsona (lekkoatletyka), Heidi (Andreasa) Krieger(a) (pchnięcie kulą), Diega Maradony (piłka nożna) lub Marii Szarapowej (tenis). 
jednej gry. To pokutujący wciąż w niektórych teoriach „mit samotnego gracza” („the myth of the isolated gamer" [tamże]). W rzeczywistości gracz może być zaangażowany równocześnie w kilka gier i mogą one zawierać się w sobie - reguły jednej z nich mogą określać to, jak należy rozumieć sukces w innej grze. To spostrzeżenie daje się uogólnić zasadą otwartości gier, mówiącą, że gracz hierarchizuje gry, w które jest zaangażowany (część z nich jest dla niego ważniejsza od innych) i reguły gry nadrzędnej (uznawanej przez niego za ważniejszą) określają to, na czym polega jego sukces w grze podrzędnej (mniej ważnej). Przykładowo: ktoś gra w szachy po to, by sprawić przyjemność drugiej osobie z jej wygranej. Wtedy przegrana partia szachów może być sukcesem szachisty, bo jest częścią gry nadrzędnej - zmierzającej do sprawienia komuś przyjemności.

Zasada znajduje potwierdzenie w nowszych systemowych i teoriogrowych koncepcjach gry, które pokazują, jak mogą w niej obowiązywać reguły z niej niepochodzące, gdy (racjonalny aksjologicznie) podmiot korzysta z hierarchicznie uporządkowanych systemów reguł (gier) przy podejmowaniu decyzji, a systemy nadrzędne określają sukces i sens działań w systemach podrzędnych. W tym ujęciu gry (w sensie systemowym) mogą się zawierać w sobie i wzajemnie interpretować. Są otwarte, bo reguły określające sukces i sens działań w grach podrzędnych pochodzą z gry nadrzędnej, w którą aktualnie zaangażowany jest gracz (Fink, 1960; Jacko, 2009, 2013; Järvinen, 2003; Juul, 2005; Pfeffer, Salancik, 1974, 1978).

Zasada otwartości gier określa strukturę racjonalnej intencji udziału w grze: racjonalny gracz postrzega reguły i cele gry w kontekście gier wobec niej nadrzędnych. Dlatego w sytuacji, gdy widzi, że gra, w jakiej bierze udział, prowadzi do unicestwienia wartości, które są dla niego ważniejsze od gry, zmieni jej przebieg lub ją przerwie (odmówi w niej uczestnictwa). Praktyki fair play w sporcie lub inicjatywy odpowiedzialności społecznej biznesu i zrównoważonego rozwoju (jeśli nie są tylko chwytem reklamowym) to przykłady aksjologicznie racjonalnych postaw - świadczą o tym, że sportowcy, menadżerowie i organizacje nie muszą ulegać złudzeniu immanencji gier: traktować kariery lub zysku tak, jakby wyznaczały one jedyny sens i nadrzędny cel życia.

W kontekście zaprezentowanych rozważań rodzi się pytanie: czy gracz jest moralnie zobowiq̨zany do tego, by przyjąć w grze postawę aksjologicznie racjonalną? Przedstawione analizy pokazują, że człowiek siebie 
do tego zobowiązuje swoimi decyzjami, wyznaczającymi jego życiowe zaangażowania i system wartości. Gracz nie musi być racjonalny w taki sposób. Może postępować nieracjonalnie, ale zachowuje się wtedy niezgodnie z przyjętymi przez siebie zasadami działania należącymi do gry uznawanej przez niego za nadrzędną - wówczas jego decyzje przestają być wyrazem jego wolności (Jacko, 2018a).

\section{Posumowanie i perspektywy badawcze}

W pracy przedstawiono analizę, która prowadzi do wyważonej odpowiedzi na tytułowe pytanie: imersja może, ale nie musi być racjonalna. Sformułowano hipotezy zaczerpnięte $\mathrm{z}$ teorii racjonalnego działania, które objaśniają tę odpowiedź. Prowadzą do wniosku, że racjonalność jest zadaniem (wyzwaniem) moralnym, jakie stoi przed graczem. Własnymi decyzjami zobowiązuje on siebie do tego, by delektując się wrażeniem, nie ulegać złudzeniu immanencji gier. Taktykę takiego panowania nad emocjami określali już pierwsi filozofowie, choć nie posługiwali się terminem „imersja”. Przykładowo, Arystoteles zauważył, że człowiek sam siebie wychowuje, kształtując własne emocje w ten sposób, by skłaniały go do racjonalnego działania. Tak uformowane, stanowią komponent utrwalonej w podmiocie postawy, które Stagiryta nazywa cnotą (gr. ảpetŕ). Ten, kto ją w sobie ma, umie się cieszyć (bawić) tym, co robi, w sposób zgodny z jego hierarchią wartości. Jeśli nawet ulegnie złudzeniu immanencji gier, podejmie pracę kształtowania swoich emocji tak, by to się nigdy potem nie powtórzyło, a jeśli się to zdarzy - porzuci grę, nad którą nie panuje.

W pracy wskazano subiektywne źródła złudzenia immanencji gier dystans estetyczny, emocje imersji i decyzje gracza. Do wytworzenia owej iluzji przyczyniają się również cechy gry i jej otoczenia. W niniejszym studium celowo pominięto ów obiektywny aspekt. Ukazuje ono jednak wyznaczający dalszą perspektywę badań problem, który można określić pytaniami: „Dlaczego niektóre gry częściej niż inne wywołują złudzenie immanencji gier?” oraz „Jakie cechy gier korelują z tym złudzeniem?”. W kontekście przeprowadzonych rozważań można postawić hipotezy stanowiące odpowiedź na te pytania: Presja otoczenia towarzysząca niektórym grom sportowym lub zarządzania (np. tzw. wyścig szczurów) 
skutkuje niekiedy tym, że ich uczestnicy ulegają opisywanemu złudzeniu. Również konstrukcja i ekonomia gier czasem temu sprzyjają - np. gry wymagające współzawodnictwa, w odróżnieniu od tych wymagających współpracy; gry wywołujące silne pobudzenie emocjonalne, takie jak agresja lub podniecenie; gry, w których nagradzane są zachowania niezgodne $z$ hierarchią wartości gracza. Wymienione przypuszczenia należy sprawdzić w dalszych badaniach.

\section{Literatura}

Anderson, C. A., Dill, K. E. (2000). Video games and aggressive thoughts, feelings and behavior in the laboratory and in life. Journal of Personality and Social Psychology, 78(4), 772-790.

Ballabio, M., Griffiths, M. D., Urbán, R., Quartiroli, A., Demetrovics, Z., Király, O. (2017). Do gaming motives mediate between psychiatric symptoms and problematic gaming? An empirical survey study. Addiction Research \& Theory, 25(5), 397-408.

Baños, R., Botella, C., Alcañiz, M., Liaño, V., Guerrero, B., Rey, B. (2004). Immersion and emotion: Their impact on the sense of presence. CyberPsychology \& Behavior, 7(6), 734-741.

Bjarg, A. (2016). Why emotional involvement is key to immersion in VR. Online: <http://medium.com/cinematicvr/why-emotional-involvement-is-key-to-true-immersion-in-vr-8a6023db88d3>.

Blix, S. B. (2015). Professional emotion management as a rehearsal process. Professions and Professionalism, 5(2), 1-15.

Bocheński, J. M. (1987). Sto zabobonów. Krótki filozoficzny słownik zabobonów. Paryż: Instytut Literacki.

Bortolotti, L. (2010). Delusions and Other Irrational Beliefs. Oxford - New York: OUP Oxford.

Brown, E., Cairns, P. (2004) A grounded investigation of game immersion. W: CHI EA '04: CHI '04 Extended Abstracts on Human Factors in Computing Systems (s. 1297-1300). New York: ACM.

Bullough, E. (1912). „Psychical distance” as a factor in art and as an aesthetic principle. British Journal of Psychology, 5(1), 87-117. 
Bushman, B. J., Anderson, C. A. (2002). Violent video games and hostile expectations: A test of the General Aggression Model. Personality and Social Psychology Bulletin, 28(12), 1679-1686.

Consalvo, M. (2005). Rule sets, cheating, and magic circles: Studying games and ethics. International Review of Information Ethics, 4(12), 7-12.

Co-to-znaczy.pl (2015). Co to znaczy pg? Power Gaming. Online: <http:// co-to-znaczy.pl/co-to-znaczy-pg-power-gaming>.

Cowley, B., Charles, D., Black, M., Hickey, R. (2008). Toward an understanding of flow in video games. Computers in Entertainment, 6(2), 1-27.

Csíkszentmihályi, M. (1975). Beyond Boredom and Anxiety. San Francisco: Jossey-Bass Publishers.

Csikszentmihalyi, M. (1990). Flow: The Psychology of Optimal Experience. New York: Harper Perennial.

Coupland, C. (2015). Entry and exit as embodied career choice in professional sport. Journal of Vocational Behavior, 90(1), 111-121.

D’Agostino, F. (1995). The ethos of games. W: J. Morgan, K. V. Meier (red.), Philosophic Enquiry in Sport (s. 42-49). Champaign [Illinois]: Human Kinetics.

Dansky, R. (2006). Introduction to game narrative. W: C. Bateman (red.), Game Writing: Narrative Skills for Videogames (s.1-23). Boston [Massachusetts]: Charles River Media.

Davis, Z., Steinbock, A. (2016). Max Scheler. W: E. N. Zalta (red.), The Stanford Encyclopedia of Philosophy (Fall 2016). Stanford: Metaphysics Research Lab, Stanford University. Online: <http://plato.stanford.edu/ archives/fall2016/entries/scheler>.

Detez, L., Greenwood, L.-M., Segrave, R., Wilson, E., Chandler, T., Ries, T., Yücel, M. (2019). A Psychophysiological and Behavioural Study of Slot Machine Near-Misses Using Immersive Virtual Reality. Journal of Gambling Studies, 35(1), 929-944.

Dixit, A., Nalebuff, B. (1991). Thinking Strategically. New York: Norton.

Dodig-Crnkovic, G., Larsson, T. (2005). Game ethics: Homo ludens as computer game designer and consumer. International Review of Information Ethics, 4(12), 19-23.

Feezell, R. M. (2004). Sport, Play, and Ethical Reflection. Urbana [Chicago]: University of Illinois Press.

Fink, E. (1960). The ontology of play. Philosophy Today, 4(2), 95-109. 
Floridi, L. (1999). Information ethics: On the philosophical foundation of computer ethics. Ethics and Information Technology, 1(1), 37-56.

Floridi, L. (2003). On the intrinsic value of information objects and the infosphere. Ethics and Information Technology, 4(4), 287-304.

Floridi, L. (2005). The ontological interpretation of informational privacy. Ethics and Information Technology, 7(4), 185-200.

Frey, B. S., Osterloh, M. (red.). (2001). Successful Management by Motivation: Balancing Intrinsic and Extrinsic Incentives. New York: Springer.

Fromm, E. (1941). Escape from Freedom. New York: Henry.

Garn, A. C., Cothran, D. J. (2006). The fun factor in physical education. Journal of Teaching in Physical Education, 25(3), 281-297.

Grüsser, S. M., Thalemann, R., Griffiths, M. D. (2007). Excessive computer game playing: Evidence for addiction and aggression? CyberPsychology E Behavior, 10(2), 290-292. Online: <http://www.liebertpub.com/doi/ pdf/10.1089/cpb.2006.9956>.

Hansson, S. O., Grüne-Yanoff, T. (2018). Preferences. W: E. N. Zalta (red.), The Stanford Encyclopedia of Philosophy (Summer 2018). Stanford: Metaphysics Research Lab, Stanford University. Online: <http://plato.stanford.edu/archives/sum2018/entries/preferences $>$.

Hilgers, T. (2016). Aesthetic Disinterestedness: Art, Experience, and the Self. New York - London: Routledge.

Hochschild, A. R. (1979). Emotion work, feeling rules, and social structure. The American Journal of Sociology, 85(3), 551-575.

Huhtamo, E. (2005). Slots of fun, slots of trouble. An archaeology of arcade gaming. W: J. Goldstein, R. Joost (red.), Handbook of Computer Games Studies (s. 1-5). Cambridge: MIT Press.

IGI Global (b.d.). What is Psychological Immersion. Online: <http://www. igi-global.com/dictionary/psychological-immersion/24008>.

Ingarden, R. (1988) O dziele literackim. Badania z pogranicza ontologii, teorii języka ifilozofii literatury (tłum. M. Turowicz). Warszawa: Wydawnictwo Naukowe PWN.

Jacko, J. F. (2009). Ontologia myślenia strategicznego. Homo Ludens, 1(1), 113-121.

Jacko, J. F. (2013). „Czym jest gra?”. Uwagi o analogicznej wieloznaczności pojęcia gry. Kontekst nauk o zarządzaniu. Homo Ludens, 5(1), 92-107. Jacko, J. F. (2015). Wewnętrzna etyka gry. Homo Ludens, 7(1), 49-64. 
Jacko, J. F. (2016). Czym jest gra? Uwagi o przedmiocie ludologii. Analiza fenomenologiczno-metodologiczna. Homo Ludens, 9(1), 65-83.

Jacko, J. F. (2018a). Moral conditions for methodologically rational decisions. Poznan Studies in the Philosophy of the Sciences and the Humanities, $111(1), 209-223$.

Jacko, J. F. (2018b). The value experience of the emotional immersion in games. Homo Ludens, 11(1), 83-100.

Järvinen, A. (2003). The Elements of Simulation in Digital Games: System, Representation and Interface in "Grand Theft Auto: Vice City". Dichtung-Digital, 5(4). Online: <http://www.dichtung-digital.de/2003/ issue/4/jaervinen/index.htm>.

Jennett, C., Cox, A. L., Cairns, P., Dhoparee, S., Epps, A., Tijs, T., Walton, A. (2008). Measuring and defining the experience of immersion in games. International Journal of Human-Computer Studies, 66(9), 641-661. Juul, J. (2005). Half-Real: Video Games between Real Rules and Fictional Worlds. Cambridge: MIT Press.

Kant, I. (2007). Critique of Judgment (tłum. J. Bernard). New York: Cosimo. King, A. (b.d.). The Aesthetic Attitude. Internet Encyclopedia of Philosophy. Online: <http://www.iep.utm.edu/aesth-at/\#SH1a>.

Komulainen, J., Takatalo, J., Lehtonen, M., Göte, M. (2008). Psychologically structured approach to user experience in games. W: K. Tollmar, B. Jönsson (red.), Proceedings of the $5^{\text {th }}$ Nordic Conference on HumanComputer Interaction, Lund, Sweden - October 18-22, 2007. New York: ACM Press.

Kreitman, N. (2006). The varieties of aesthetic disinterestedness. Contemporary Aesthetics, 4(1). Online: <http://www.contempaesthetics.org/ newvolume/pages/article.php?articleID=390>.

Latham, G. P. (2012). Work Motivation: History, Theory, Research, and Practice. Los Angeles: SAGE.

Lindley, C. A., Nacke, L., Sennersten, C. C. (2008). Dissecting Play: Investigating the Cognitive and Emotional Motivations and Effects of Computer Gameplay. W: Proceedings of CGAMES $2008-13^{\text {th }}$ International Conference on Computer Games: AI, Animation, Mobile, Educational and Serious Games. Wolverhampton: University of Wolverhampton.

Mandryk, R. L., Inkpen, K. M. (2004). Physiological indicators for the evaluation of co-located collaborative play. Proceedings of the 2004 ACM 
Conference on Computer Supported Cooperative Work: CSCW 2004, Chicago, Illinois, USA, November 6-10, 2004. New York: ACM. Online: <http:// www.researchgate.net/publication/220879431_Physiological_indicators_for_the_evaluation_of_co-located_collaborative_play>.

Mathiak, K., Weber, R. (2006). Toward brain correlates of natural behavior: MRI during violent video games. Human Brain Mapping, 27(12), 948-956.

McCormick, M. (2001). Is it wrong to play violent video games? Ethics and Information Technology, 3(4), 277-287.

McDonald, W. (2017). Søren Kierkegaard. W: E. N. Zalta (red.), The Stanford Encyclopedia of Philosophy (Winter 2017). Stanford: Metaphysics Research Lab, Stanford University. Online: <http://plato.stanford.edu/ archives/win2017/entries/kierkegaard $>$.

Nacke, L. E., Drachen, A., Kuikkaniemi, K., Niesenhaus, J., Korhonen, H. J., Hoogen, W. M., Kort, Y. (2009). Playability and player experience research. W: Breaking New Ground: Innovation in Games, Play, Practice and Theory Proceedings of DiGRA 2009 (s. 1-4). Online: <http://www. researchgate.net/publication/30498586_Playability_and_Player_Experience_Research_Pre-print>.

Nacke, L., Lindley, C. (2009). Affective Ludology, Flow and Immersion in a First-Person Shooter: Measurement of Player Experience. Loading..., 3(5). Online: <http://journals.sfu.ca/loading/index.php/loading/ article/view/72>.

Ortony, A., Clore, L., Collins, A. (1990). The Cognitive Structure of Emotions. Cambridge: Cambridge University Press.

Pfeffer, J., Salancik, G. R. (1978). The External Control of Organization: A Resource Dependence Perspective. New York: Harper \& Row.

Qin, H., Rau, P. L. P., Salvendy, G. (2009). Measuring player immersion in the computer game narrative. International Journal of Human-Computer Interaction, 25(2), 107-133.

Qin, H., Rau, P. L. P., Salvendy, G. (2010). Effects of different scenarios of game difficulty on player immersion. Interacting with Computers, $22(3), 230-239$.

Ravaja, N., Turpeinen, M., Saari, T., Puttonen, S., Keltikangas-Järvinen, L. (2008). The psychophysiology of James Bond: Phasic emotional responses to violent video game events. Emotion, 8(1), 114-120. 
Ravaja, N., Saari, T., Laarni, J., Kallinen, K., Salminen, M., Holopainen, J. (2005). The psychophysiology of video gaming: Phasic emotional responses to game events. W: S. de Castell, J. Jenson (red.), Changing Views: Worlds in Play: Selected Papers of the 2005 Digital Games Research Association's Second International Conference, [June 16-20, 2005, Vancouver, British Columbia, Canada] (s. 1-13). Burnaby: Tampere.

Ravaja, N., Saari, T., Salminen, N., Laarni, J., Kallinen, K. (2009). Phasic Emotional Reactions to Video Game Events: A Psychophysiological Investigation. Media Psychology, 12(4), 343-367.

Roberts, G. C., Treasure, D. (red.). (2018). Advances in Motivation in Sport and Exercise. Champaign: Human Kinetics.

Schaufeli, W., Maslach, C., Marek, T. (red.). (1996). Professional Burnout: Recent Developments in Theory and Research. Philadelphia: Taylor \& Francis. Seah, M., Cairns, P. (2008). From immersion to addiction in videogames. W: D. England i in., People and Computers XXII - Culture, Creativity and Interaction: Proceedings of the 22nd British HCI Group Annual Conference on People and Computers, Liverpool John Moores University, U.K., 1-5 September 2008 (s. 55-63). Swinton [UK]: British Computer Society.

Shelley, J. (2013). The Concept of the Aesthetic. W: E. N.Zalta (red.), The Stanford Encyclopedia of Philosophy (Fall 2013). Stanford: Metaphysics Research Lab, Stanford University. Online: <http://plato.stanford.edu/ archives/fall2o13/entries/aesthetic-concept>.

Stolnitz, J. (1961). On the Origins of "Aesthetic Disinterestedness". The Journal of Aesthetics and Art Criticism, 20(2), 131-143.

Sweetser, P., Wyeth, P. (2005). Game flow: a model for evaluating player enjoyment in games. Computers in Entertainment (CIE), 3(3), 3.

Takatalo, J., Häkkinen, J., Kaistinen, J., Nyman, G. (2010). Presence, involvement, and flow in digital games. W: R. Bernhaupt (red.), Evaluating User Experience in Games (s. 23-46). London: Springer.

Taylor, T. L. (2003) Power gamers just want to have fun?: Instrumental play in a MMOG. W: M. Copier, J. Raessens (red.), Level Up: Digital Games Research Conference, 4-6 November 2003, Utrecht University (s. 300-311). Utrecht: Utrecht University.

Van Gordon, W., Shonin, E., Diouri, S., Garcia-Campayo, J., Kotera, Y., Griffiths, M. D. (2018). Ontological addiction theory: Attachment to me, mine, and I. Journal of Behavioral Addictions, 7(4), 892-896. 
Weber, M. (1985). Gesammelte Aufsätze zur Wissenschaftslehre. Tübingen: Mohr Siebeck.

Zimmerman, M. J. (2001). The Nature of Intrinsic Value. Lanham: Rowman \& Littlefield.

Zimmerman, M. J. (2015). Intrinsic vs. Extrinsic Value. W: E. N. Zalta (red.), The Stanford Encyclopedia of Philosophy (Spring 2015). Stanford: Metaphysics Research Lab, Stanford University. Online: <http://plato. stanford.edu/archives/spr2015/entries/value-intrinsic-extrinsic $>$.

Zhang, C., Perkis, A., Arndt, S. (2017). Spatial Immersion versus Emotional Immersion, which is More Immersive? Presented at the Conference: 9th International Conference on Quality of Multimedia Experience, Erfurt. Online: <http://www.researchgate.net/publication/317357598_Spatial_ Immersion_versus_Emotional_Immersion_Which_is_More_Immersive >.

Data dostępu do źródeł internetowych wykorzystanych w tekście: 17 grudnia 2019.

dr hab. Jan F. Jacko, prof. UJ - doktor nauk humanistycznych (filozofia), habilitacja $w$ dziedzinie humanistycznych nauk o zarządzaniu. Obszary specjalizacji: teoria racjonalnej decyzji, teoria gier, etyka zarządzania. Autor lub wspótautor kilku monografii. Ostatnia (Taktyki negocjacyjne w kontekście proksemiki. Analiza metodologiczna, 2012) dotyczy przestrzennej intencjonalności ludzkich działań

dr Małgorzata Jacko - doktor nauk humanistycznych o kulturze fizycznej. Zatrudniona na Akademii Wychowania Fizycznego w Krakowie w Zakładzie Historii i Organizacji Rekreacji. Problematyka badawcza: historia i organizacja kultury fizycznej w Europie

\section{Czy zaangażowanie w grę jest racjonalne? Imersja emocjonalna w zabawie, zarządzaniu i sporcie}

Abstrakt: Praca przedstawia analizę fenomenologiczną doświadczenia imersji emocjonalnej w grach należących do zabawy, sportu i zarządzania. Celem tekstu jest odpowiedź na jego tytułowe pytanie. Przywołano hipotezy wyjaśniające doświadczenie imersji emocjonalnej, które zostały zaczerpnięte z teorii racjonalnego działania. Wskazano dwa rodzaje imersji: ten, który spełnia wymagania racjonalności, i ten, który ich nie spełnia.

Słowa kluczowe: zarządzanie wrażeniami, zarządzanie jakością, zabawa, sport, kultura fizyczna, racjonalność, imersja 
